\title{
Histone H2A Type 2-C
}

National Cancer Institute

\section{Source}

National Cancer Institute. Histone H2A Type 2-C. NCI Thesaurus. Code C162974.

Histone H2A type 2-C (129 aa, $14 \mathrm{kDa}$ ) is encoded by the human H2AC20 gene. This protein plays a role in DNA condensation. 